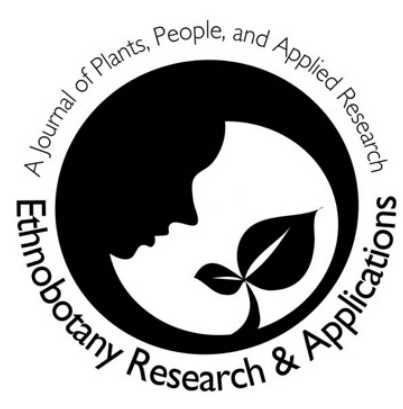

\title{
Ethnobotanical study of indigenous knowledge on medicinal plants used by the tribal communities in tehsil "Karnah" of District Kupwara (Jammu and Kashmir) India
}

Mohammad Asif, Shiekh Marifatul Haq, Umer Yaqoob, Musheerul Hassan and Hammad Ahmad Jan

\section{Research}

\begin{abstract}
Background: A fair amount of ethnobotanical knowledge of wild plant species is still held by the native people of the Himalayan mountainous region. The present study quantified the ethnobotanical usage of plants in a remote tehsil (Karnah) of district Kupwara, Jammu and Kashmir, evaluating the traditional medicinal plants use against various diseases.
\end{abstract}

Methods: This study was conducted in 2019 and 2020 to collect information regarding different ethnomedicinal uses of plant species growing in the region through questionnaires and semi-structured interviews. Multivariate ecological community analysis was used to find the relationship between ethnobotanical usage and plant species.

Results: Floristically, a total of 29 plant species belonging to 25 genera were used as medicine. Asteraceae was the largest family with $14 \%$ species. The results of preference analysis showed a significant difference in plant part usage $\left(x^{2}=70.587\right.$, $\mathrm{df}=9, \mathrm{p}<0.001)$. The highest priority of local people was for leaves $(38 \%)$. The most frequently usage was against stomach problems $(20 \%)$. The dendrogram generated five distinctly separate clusters based on the usage of wild plant as traditional medicines against various diseases. A majority of the local people (81.33\%) used traditional medicines and $49.23 \%$ regarded traditional medicines as always effective.
Conclusions: This study provides a useful self-care tool for the native people of the Kashmir Himalayas and other similar Himalayan mountainous region. Further, this study will help in developing scientifically-informed strategies for conservation of medicinal resources and sustainable use of plant diversity in this part of Himalayan region.

Keywords: Ethno-botanical usage; medicinal plants; Hakeems; Kashmir Himalayas

\section{Correspondence}

Mohammad Asif', Shiekh Marifatul Haq², Umer Yaqoob $^{2}$, Musheerul Hassan ${ }^{3}$, Hammad Ahmad $\operatorname{Jan}^{4 *}$

${ }^{1}$ Department of Botanical and Environment Science, Guru Nanak Dev University Amritsar Punjab143005, India

${ }^{2}$ Wildlife Crime Control Division, Wildlife Trust of India, Noida 201301, India

${ }^{3}$ Clybay Private limited, Bangalore, India - 560114

${ }^{4}$ Department of Botany, University of Buner, Swari, Pakistan

*Corresponding Author: hajmughul@yahoo.com

Ethnobotany Research \& Applications

21:02 (2021) 


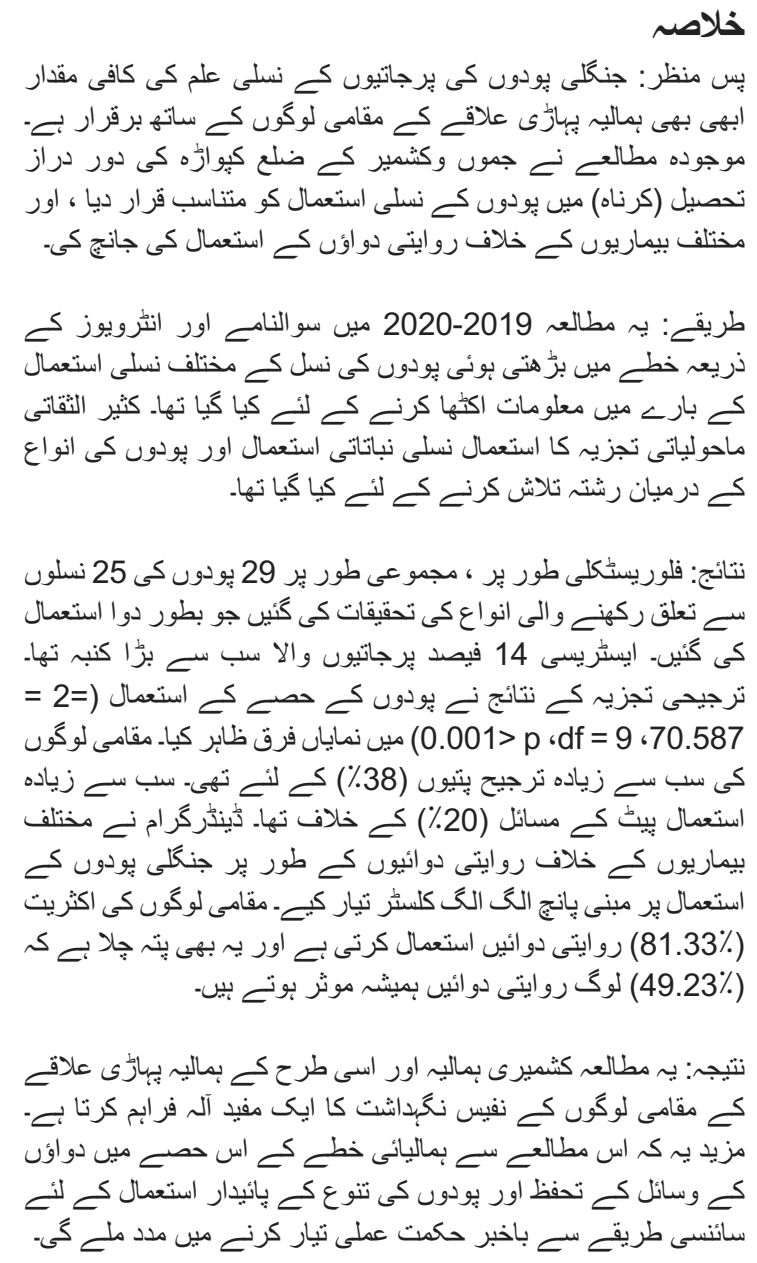

\section{Background}

Forests and wild plants are known to play an important role in meeting the health and nutritional necessities of people all over the world (Setalaphruk and Price 2007; Singh 2004). Wild herbs are found to play a significant role in the livelihood of tribal people (Jadhav et al. 2011). India, being world's second most populous country is characterized by having more than $75 \%$ of the population living in rural areas (https://censusindia.gov.in/2011census/ population_enumeration.html) and a large chunk of these people depend on wild edibles and medicinal plants to meet their needs of food as well as medicines (Rashid et al. 2008). It is estimated that in India about 800 plant species are consumed as food and medicinal plants, chiefly by the tribal inhabitants (Med 2017).

Since prehistoric times, mankind all over the world have studied and practiced the utilization of plants growing in their surroundings for curing various diseases (Yuan et al. 2016; Sewell 2014). From ancient times, the Indians have been using local medicinal plants growing in their surrounding as indigenous drugs and have played a pioneering role in the evolution of modern medicinal allopathic and traditional systems (Kala et al. 2006). Ethno-medical practices are the basis of medicinal systems such as Siddha, Unani, Sowa-Rigpa, Ayurveda and even used in the allopathic system (Roy 2020). It is estimated by WHO that about four-fifth of people present in the developing regions are depending on plant derived medicines (World Health Organization 2003) and large populations of third world countries use these traditional due to their presence in their close vicinity (Allkin 2017). Manyost of the drugs utilized in the allopathic system originated from plant compounds (Aziz et al. 2017).

Ethnobotanical studies have depicted the vital association between the use of plants and tribal communities (Pieroni et al. 2002; Turner and Tjørve, 2005; Verpoorte et al. 2005; Singh and Lal 2008; Mahmood et al. 2011). Traditional knowledge is still passed from generation to generation, but cultural contact, accelerating land degradation, developmental activities and deforestation have resulted in migration of tribal populations from their homelands, and knowledge is slowly lost. The conservation of this treasured primordial information requires immediately documentation. Ethnobotanical surveys investigate how these plants resources are utilized as medicine, fuel wood, food, shelter, agriculture, timber, furniture, fodder and religious ceremonies (Khan et al. 2003).

This study represents the first quantitative ethnobotanical survey from this part of Himalayan region. It will help in developing scientifically-informed strategies for the conservation of natural resources and sustainable use of plant diversity in this part of Himalayan region.

\section{Materials and Methods \\ Study area}

The Himalayan Region of India is considered as one of the largest biodiversity hotspots of the world and occupies about $40 \%$ of the land area of India (Kumar et al. 2011). Karnah is a tehsil in Kupwara district of Jammu and Kashmir, India. Karnah is $180 \mathrm{~km}$ towards the north of Srinagar and about $80 \mathrm{~km}$ from district headquarters Kupwara, which lies at 34.39' N latitude and 73.86' E longitude (Fig.- 1). The altitude of the area ranges between 1380 to 3300 masl. Karnah has a population of 60129 as per census 2011. Languages spoken are Pahari, Gojjari and Kashmiri. About $70 \%$ of the population speaks Pahari, the rest speaks Gojjari and only two villages speak Kashmiri (Hajinar and Baghballa). Most of population of the area is Muslim except for one village (Terbondhiyan) which is Sikh. The average literacy rate of the area is $63.65 \%$ as per census 2011. 

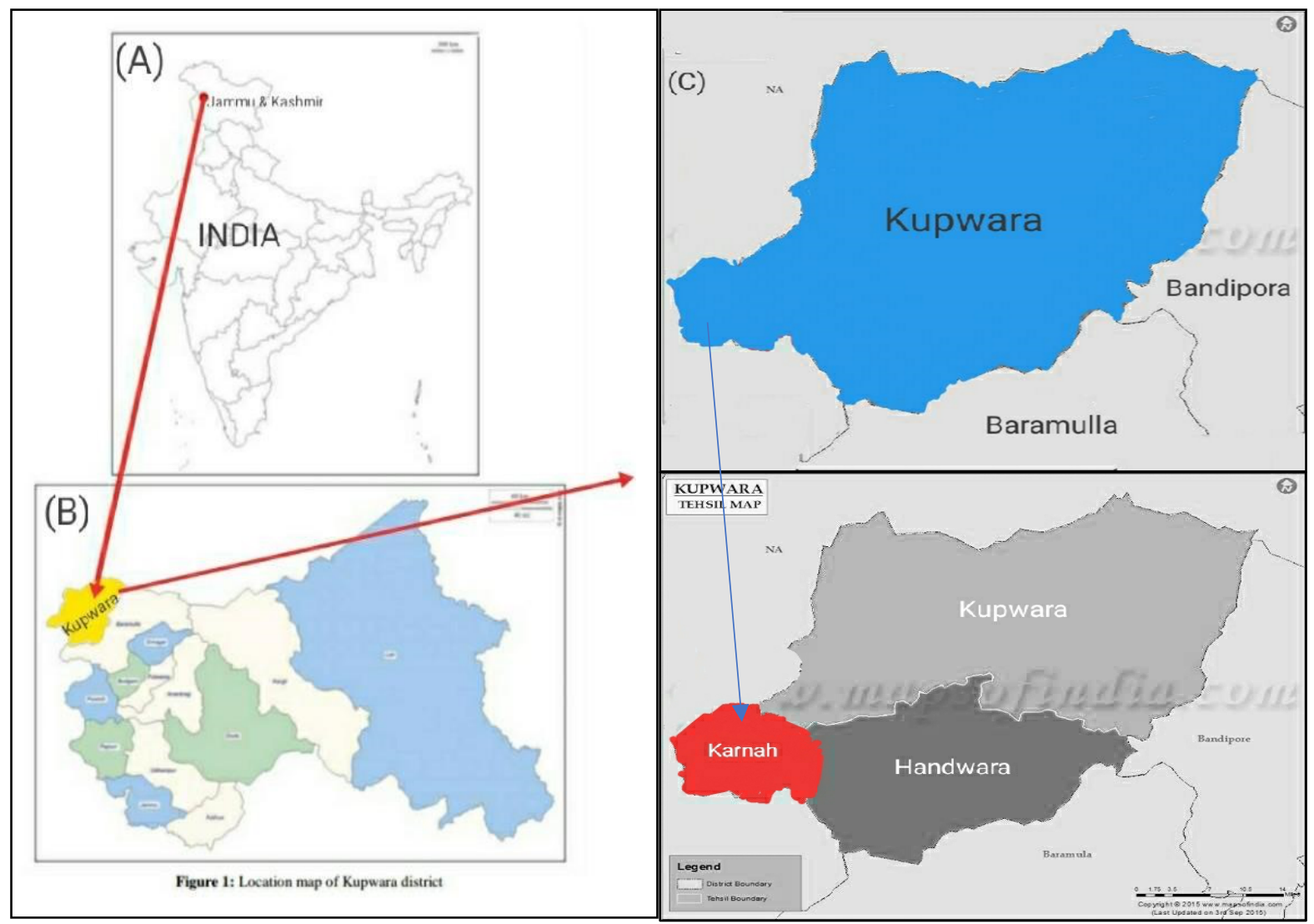

Fig. 1. Map of the study area

The region is located in the lap of Shamasbari and Kranu mountains of the lesser Himalayas. The climate in district Kupwara including tehsil Karnah is warm and humid. Kupwara has considerable precipitation throughout the year and is considered as Cfa (Humid subtropical climates or mild temperate climates) by Koppen and Geiger. In Kupwara the average annual temperature is $14.1^{\circ} \mathrm{C}$. Precipitation here average $843 \mathrm{~mm}$ (https://en.climatedata.org/asia/india/jammu-and-kashmir-751/) with well-defined four seasons in a year. It experiences pleasant weather from April to October with scanty rainfall and is thickly forested in the region. The region is rich in various economically important medicinal and aromatic plants like Aconitum heterophyllum Wall. ex Royle, Bergenia ciliata (Haw.) Sternb, Aucklandia costus Falc., and Taxus wallichiana Zucc.

\section{Methodology}

The present study is based on a carefully planned field survey. Representative villages $(\mathrm{N}=3)$ were visited during the year 2019 and 2020. The methodology was based on interviews using semistructured and closed ended questionnaires and group discussions to document the local ethnobotanical knowledge on uses of plant resources (Khan et al. 2011; Abbas et al. 2017). The information was collected from diverse groups of the area, i.e. Hakeems (traditional doctors), hunters, herders and other common citizens like cultivators/agricultural laborers, skilled/semi-skilled workers, daily wage laborers, housewives, shopkeepers, Govt. employees and students. All interviews were conducted only after obtaining prior informed consent of the village heads, tribal leaders and individual informants, by explaining clearly the objectives of the study. The most important ethnic groups are the Hakeems, Gujjar/Barkawals and herders who are directly dependent on wild plant products for their livelihood. (Table 1). A local community member of these tribes who knew the norms and traditions of that indigenous society was taken as a guide. Informants were asked about the conventional uses of wild flora species, methods of preparation of ethnomedicinal recipes, performance of ethnomedicine against the disease. Informants were further asked about parts of flora used e.g., leaves, roots, bark, fruits, and flowers, etc. The field study was carried out in diverse age-sex groups (young, old and middle). Field-based personal observations, information from local informers and both formal and informal discussions were carried out for additional information. 
Table 1. Demographic status of the respondents from the study area.

\begin{tabular}{|c|c|c|}
\hline DEMOGRAPHIC FEATURES & NUMBER OF PEOPLE & PERCENTAGE \\
\hline Bio-geographic areas & 610 & \\
\hline Budwan & 100 & 16.39 \\
\hline Baghballa & 251 & 41.14 \\
\hline Nachiyian & 259 & 42.45 \\
\hline \multicolumn{3}{|l|}{ Education } \\
\hline Illiterate & 372 & 60.98 \\
\hline Primary education & 153 & 25.08 \\
\hline Secondary education & 67 & 10.98 \\
\hline Higher education & 18 & 2.95 \\
\hline \multicolumn{3}{|l|}{ Age range (Years) } \\
\hline $30-40$ & 141 & 23.11 \\
\hline $41-50$ & 161 & 26.39 \\
\hline $51-60$ & 213 & 34.91 \\
\hline $61-70$ & 56 & 9.18 \\
\hline$>70$ & 39 & 6.39 \\
\hline \multicolumn{3}{|l|}{ Profession } \\
\hline Cultivators/ Agricultural labourers & 169 & 27.70 \\
\hline Daily wage laborers & 115 & 18.85 \\
\hline Skilled/semi-skilled workers & 78 & 12.78 \\
\hline Housewives & 122 & 20.00 \\
\hline Shopkeepers & 42 & 6.88 \\
\hline Students & 31 & 5.08 \\
\hline Herders & 35 & 5.73 \\
\hline Govt. employees & 11 & 1.80 \\
\hline Hakeem's & 7 & 1.14 \\
\hline \multicolumn{3}{|l|}{ Gender } \\
\hline Male & 413 & 67.70 \\
\hline Female & 197 & 32.29 \\
\hline
\end{tabular}

The Plant List and POWO 2019 (www.theplantlist.org;

http://www.plantsoftheworldonline.org/) were used for the updated nomenclature of recorded species from study area. From each selected site, plant specimens were collected for the authentication and herbarium preparation. Plant specimens were identified using relevant taxonomic literature and with the help of taxonomists at Centre of Biodiversity and Taxonomy, University of Kashmir, Srinagar (J\&K). Later the doubtful plants specimens were verified by deposited herbarium specimens at the Kashmir University Herbarium (KASH herbarium). After, incorporation of field data on herbarium sheets, the vouchers were deposited at $\mathrm{KASH}$ Herbarium.

\section{Data analysis}

Plant data were statistically analyzed to elucidate the relationship between ethnobotanical usage and plant species. The presence/absence (1/0) data were subjected to the classification of different ethnomedicinal differences and similarities among the diverse plant medicinal usage via PAST software (Hammer et al. 2001; Greig-Smith, 2010). Using this method, more similar groups come close to each other and dissimilar groups are shown as distant in the cluster from each other. Sørensen's (Bray-Curtis) distance was used to identify significant differences among the different ethnobotanical usage similarities (Sorensen, 1948; Dalirsefat et al. 2009). Principal Component Analysis (PCA) was done to visualize 
the provisioning services and plant parts associations between plants using PAST software.

\section{Results}

\section{Profile of respondents}

We conducted interviews of 610 informants, of which 100 were from Budwan village, 297 from Baghballa and 313 from Nachiyian village of tehsil Karnah in Kupwara district. Out of the total informants interviewed, 413 (68\%) were men and 197 (32\%) were women . During our study, the respondents interviewed included cultivators/agricultural laborers (28\%), housewives $(20 \%)$, daily wage laborers (19\%), skilled/semi-skilled workers (13\%), shopkeepers $(7 \%)$, herders $(5 \%)$, students $(5 \%)$, Govt. employees (2\%) and Hakeems (1\%). The age of the respondents ranged between 20 to 70 years. Most of the respondents belonged to age group 5160 (34.91) followed by 31-40 (29\%) 41-50 (27\%), 61$70(9.18)$ and lowest age respondents $(7 \%)$ belong to 70 or above age group in the regions. More than half of the respondents were without formal education (45\%), while most of those with education had merely primary $(25 \%)$ followed by $(11 \%)$ having education up to $10^{\text {th }}$ and least $(3 \%)$ having higher education.

\section{Vegetation composition and distribution}

A total of 29 plant species belonging to 25 families were reported in the course of the study as shown in Table 2. The useful flora of the region can be classified into trees $(7 \%)$, shrubs (17\%), and herbs (76\%). The species distribution across the 25 families was unequal; half of the species belonged to just 11 families while as the remaining half belonged to 14 families. A large number of families (22) were found to be represented by only one species, (Table 2). The dominant plant families included Asteraceae with $14 \%$ of the total species followed by Ranunculaceae $(10 \%)$ of species. The details of reported plant species are given in Table 2 and Fig 2.

\section{Plant part used}

The results of preference analysis showed a significant difference in plant part usage $\left(X^{2}=70.587\right.$, $d f=9, p<0.001)$. The highest priority of local people was for leaves $(37 \%)$ followed by roots $(24 \%)$ and others having less than $10 \%$ of preference in show in Fig. 3. This fact is also supported by principal components analysis (PCA) analyses showed three distinct groups based on the variations in the preference levels of plant part usage. PC1 and PC2 explained $5.9 \%$ of similarity of plant parts in the biplot (Fig.4), in which specific groups of plant parts were more related to specific provisioning services than others. Roots and leaves were distinctly separated from each other, while other parts formd separate group (Fig.4).

\section{Traditional medicines against various diseases}

The most frequently cited usage of plants was against stomach problems $(20 \%)$ followed by bone and joints (17\%), cough, cold and fever (15\% each) (Fig.5). Maximum (83\%) of medicinal plants (Aconitum heterophyllum Wall. ex Royle, Adiantum capillus-veneris L, Bergenia ciliate (Haw.) Sternb. Aucklandia costus Falc., and Taxus wallichiana Zucc.) were used to cure single diseases, followed by $(17 \%)$ of plants (e.g. Anemone tschernjaewii Regel, Artemisia absinthium L, Rheum webbianum Royle, Rhododendron campanulatum D. Don) used to cure more than one disease.

The dendrogram generated five distinctly separate clusters based on the usage of wild plant as traditional medicines against various diseases (Fig.6). The clusters that grouped in one limb are more similar in plant usage to cure these diseases. However, the cluster limb one and five displayed maximum dissimilarity with their neighbor clusters. Moreover, the similarity in usage decreased with increasing distance between groups (cluster). The dendrogram generated five (5) distinctly separate clusters based on plant usage for disease cure: cluster one- abdominal problems and obesity; cluster two - kidney problems; asthma, healing and cancer; cluster three-fever and cold \& cough; The stomach problems and bone and joints form $4^{\text {th }}$ and $5^{\text {th }}$ cluster of the dendrogram. The Two-Way Cluster Analyses of both the ethnobotanical usage and plant species resulted in 5 major clusters (Fig 6).

\section{Efficacy of traditional medicines}

A majority of the local people (81.33\%) used traditional medicines for medication while rest (18.67) did not prefer to uses traditional medicines. A total of $83.80 \%$ of the local inhabitants prepared their own traditional remedies and $16.19 \%$ obtain it from Hakeems. We found that a majority $(49.23 \%)$ of the people indicated that traditional medicines were always effective followed by $45 \%$ who believed that these are sometimes effective and only $5.77 \%$ responded that they were never effective. 
Table 2. Plant species, family, local name, habitat, part used and method of preparation and application of plant in the study area.

\begin{tabular}{|c|c|c|c|c|c|c|}
\hline Botanical name & Family & Local Name & Habitat & $\begin{array}{l}\text { Specimen } \\
\text { number }\end{array}$ & Part Used & Method of Preparation and Application \\
\hline $\begin{array}{l}\text { Sambucus wightiana } \\
\text { Wall. ex Wight \& Arn. }\end{array}$ & Adoxaceae & Ganullo & Shrub & SHM-KH-256 & $\begin{array}{l}\text { Leaves, } \\
\text { roots }\end{array}$ & $\begin{array}{l}\text { Edible roots are eaten in small amount to treat asthma. Dried and } \\
\text { ground leaves are applied for wound healing mostly in cattle. }\end{array}$ \\
\hline Amaranthus viridis $\mathrm{L}$. & Amaranthaceae & Kanhaar & Herb & SHM-KH-235 & Seeds & $\begin{array}{l}\text { Dried seeds of the plant are boiled for a day and decoction is } \\
\text { either drunk to cure sneezing or rhinorrhoea or corn flour is added } \\
\text { to the decoction along with ghee and relished as "Kher" to relieve } \\
\text { back pain. }\end{array}$ \\
\hline $\begin{array}{l}\text { Angelica glauca } \\
\text { Edgew. }\end{array}$ & Apiaceae & Choro & Herb & SHM-KH-238 & Leaves & $\begin{array}{l}\text { A recipe made with the combination of leaves of the plant and } \\
\text { kidney bean curry is taken to treat obesity. }\end{array}$ \\
\hline Achillea millefolium $\mathrm{L}$. & Asteraceae & Dandjadi & Herb & SHM-KH-231 & Root, leaves & $\begin{array}{l}\text { Is proved to be most effective to relieve toothache if a tuft of its } \\
\text { leaves is grasped in tooth for a while. }\end{array}$ \\
\hline $\begin{array}{l}\text { Artemisia absinthium } \\
\mathrm{L}\end{array}$ & Asteraceae & Chaoow & Herb & SHM-KH-240 & Shoot sap & $\begin{array}{l}\text { Juice of the grinded leaves drunk to treat diabetes and abdominal } \\
\text { pain. }\end{array}$ \\
\hline $\begin{array}{l}\text { Aucklandia costus } \\
\text { Falc. }\end{array}$ & Asteraceae & Kuth & Herb & SHM-KH-257 & Roots & $\begin{array}{l}\text { Dried roots are ground into a fine powder and mixed with boiling } \\
\text { water or milk or cooked with rice and are taken as tonic for the } \\
\text { treatment of joint pain, rheumatism and cough. }\end{array}$ \\
\hline $\begin{array}{l}\text { Taraxacum officinale } \\
\text { (L.) Weber ex F.H. } \\
\text { Wigg. }\end{array}$ & Asteraceae & Hannd & Herb & SHM-KH-258 & Leaves & $\begin{array}{l}\text { Leaves are consumed as vegetables and are especially served to } \\
\text { women as a tonic who has recently delivered a baby. }\end{array}$ \\
\hline $\begin{array}{l}\text { Berberis asiatica } \\
\text { Roxb. ex DC. }\end{array}$ & Berberidaceae & Sumloo & Shrub & SHM-KH-241 & Roots & $\begin{array}{l}\text { Roots are grinded into a fine powder along with water and a paste } \\
\text { is prepared and the paste is then applied to treat bone fracture. }\end{array}$ \\
\hline $\begin{array}{l}\text { Arnebia benthamii } \\
\text { (Wall. ex G. Don) I.M. } \\
\text { Johnst. }\end{array}$ & Boraginaceae & Gazbaan & Herb & SHM-KH-239 & $\begin{array}{l}\text { Roots and } \\
\text { rhizome }\end{array}$ & $\begin{array}{l}\text { Decoction of rhizome in sugary water is sipped to alleviate } \\
\text { common cold, cough, and fever. }\end{array}$ \\
\hline Cannabis sativa $\mathrm{L}$. & Cannabaceae & Bhang & Shrub & SHM-KH-243 & Leaves & $\begin{array}{l}\text { Fresh or dried leaves along with sugar are ground together and } \\
\text { one cup of water is added into it. This mixture is then filtered with } \\
\text { a piece of cloth and drunk against loss of appetite. }\end{array}$ \\
\hline Equisetum arvense L. & Equisetaceae & Deelo & Herb & SHM-KH-246 & whole plant & $\begin{array}{l}\text { Whole plant is ground on a hard stone with water and put into a } \\
\text { jug thereby making juice by pouring water and the juice so } \\
\text { obtained is drunk to treat kidney problems. }\end{array}$ \\
\hline $\begin{array}{l}\text { Rhododendron } \\
\text { campanulatum D. Don }\end{array}$ & ae & Ingo & Shrub & SHM-KH-253 & Flowers & $\begin{array}{l}\text { Dried crushed flowers are smoked in cigarette to treat } \\
\text { rhinorrhoea, sneezing, cough and headache. }\end{array}$ \\
\hline $\begin{array}{l}\text { Indigofera heterantha } \\
\text { Brandis }\end{array}$ & Fabaceae & Kanthi & Shrub & SHM-KH-247 & Leaves & $\begin{array}{l}\text { Partially chewed leaves are applied on wounds to stop bleeding } \\
\text { as a coagulant/ clotting factor. }\end{array}$ \\
\hline Mentha arvensis $\mathrm{L}$. & Lamiaceae & Pudino & Herb & SHM-KH-248 & Leaves & $\begin{array}{l}\text { Leaves of the plant along with ground nuts and milk are grinded } \\
\text { and made into a sauce which is }\end{array}$ \\
\hline Plantago lanceolata L. & Plantaginaceae & $\begin{array}{l}\text { Chamchi- } \\
\text { Patar }\end{array}$ & Herb & SHM-KH-251 & Seeds & Seeds of the plant are boiled and taken to treat typhoid fever. \\
\hline
\end{tabular}




\begin{tabular}{|c|c|c|c|c|c|c|}
\hline $\begin{array}{l}\text { Cynodon dactylon (L.) } \\
\text { Pers. }\end{array}$ & Poaceae & Khabbal & Herb & SHM-KH-244 & Roots & $\begin{array}{l}\text { Drinking the juice of its roots with empty stomach in the morning is } \\
\text { good in normalizing sugar level (hyperglycemia). }\end{array}$ \\
\hline $\begin{array}{l}\text { Rheum webbianum } \\
\text { Royle }\end{array}$ & Polygonaceae & Chatiyaal & Herb & SHM-KH-252 & $\begin{array}{l}\text { Fruit,roots, } \\
\text { leaves }\end{array}$ & $\begin{array}{l}\text { Powdered fruits of the plant and Berberis mixed with small amount } \\
\text { of water to make a paste which is applied on a fractured bone } \\
\text { twice or thrice in a week proved to be best for fracture healing. }\end{array}$ \\
\hline Anagallis arvensis $\mathrm{L}$. & Primulaceae & Kanain & Herb & SHM-KH-236 & Leaves & $\begin{array}{l}\text { Leaves of the plant are poured in hot or boiling water to make tea } \\
\text { and are taken to treat stomach problems and high fever. }\end{array}$ \\
\hline $\begin{array}{l}\text { Adiantum capillus- } \\
\text { veneris } \mathrm{L} \text {. }\end{array}$ & Pteridaceae & Kakwaa & Herb & SHM-KH-234 & Leaves & $\begin{array}{l}\text { The dried powered fronds are mixed with milk and given as a } \\
\text { remedy for fever to infants. Leaves of the plants are mixed with } \\
\text { Cardomom and boiled in water and given to cure cough, cold and } \\
\text { fever in infants. }\end{array}$ \\
\hline $\begin{array}{l}\text { Aconitum } \\
\text { heterophyllum Wall. } \\
\text { ex Royle }\end{array}$ & Ranunculaceae & Ptrees & Herb & SHM-KH-232 & Roots & $\begin{array}{l}\text { Dried powdered roots are taken and sometimes dried roots are } \\
\text { chewed for treatment of abdominal pain and also as anthelmintic. }\end{array}$ \\
\hline $\begin{array}{l}\text { Aconitum violaceum } \\
\text { Jacquem. ex Stapf }\end{array}$ & Ranunculaceae & Ptrees & Herb & SHM-KH-233 & $\begin{array}{l}\text { Flowers, } \\
\text { roots }\end{array}$ & $\begin{array}{l}\text { Flowers are collected, dried and powdered during summer season } \\
\text { and then applied during winters to treat common cold and } \\
\text { sneezing. }\end{array}$ \\
\hline $\begin{array}{l}\text { Anemone } \\
\text { tschernjaewii Regel }\end{array}$ & Ranunculaceae & Rattanjogh & Herb & SHM-KH-237 & Rhizome & $\begin{array}{l}\text { Dried rhizome is ground into fine pieces and mixed with boiling } \\
\text { water or milk followed by sieving. Then sieved liquid extract is } \\
\text { taken }\end{array}$ \\
\hline Rubus ellipticus Sm. & Rosaceae & Kranchhi & Herb & SHM-KH-254 & Roots & $\begin{array}{l}\text { Roots of the plant are ground and soaked in water overnight and } \\
\text { four or five tea spoon of decoction so obtained is mixed in a glass } \\
\text { of water and drunken empty stomach in the morning to treat the } \\
\text { jaundice. }\end{array}$ \\
\hline Salix alba L. & Salicaceae. & Beenso & Tree & SHM-KH-255 & Twigs & $\begin{array}{l}\text { A brush made of twig is rubbed gently around the teeth and gums } \\
\text { to relieve toothache and also for tooth cleaning. Sometimes } \\
\text { leaves of the plant are putted around the head and fasten tightly } \\
\text { with a scarf to relieve headache. }\end{array}$ \\
\hline $\begin{array}{l}\text { Bergenia ciliata } \\
\text { (Haw.) Sternb. }\end{array}$ & Saxifragaceae & Batpeva & Herb & SHM-KH-242 & $\begin{array}{l}\text { Rhizome, } \\
\text { leaves }\end{array}$ & $\begin{array}{l}\text { The rhizome is cleaned and ground into a coarse powder. The } \\
\text { powder is mixed with boiling milk and taken as tea which is a good } \\
\text { medicine for diarrhoea and other gastrointestinal infections. }\end{array}$ \\
\hline Datura stramonium L. & Solanaceae & Taturo & Herb & SHM-KH-245 & Seeds & $\begin{array}{l}\text { Two or three pair of black coloured seeds is eaten to treat } \\
\text { prolonged cough, cold and sneezing. }\end{array}$ \\
\hline $\begin{array}{l}\text { Taxus wallichiana } \\
\text { Zucc. }\end{array}$ & Taxaceae & Paronghi & Tree & SHM-KH-259 & Bark & Outer bark of the plant is taken in tea as anticancer. \\
\hline $\begin{array}{l}\text { Pilea microphylla (L.) } \\
\text { Liebm. }\end{array}$ & Urticaceae & Cheekal & Herb & SHM-KH-250 & Stem, leaves & $\begin{array}{l}\text { Stem part of the plant are grinded into a course powder is mixed } \\
\text { with two or three eggs thereby making oblate and the oblate is } \\
\text { then taken with tea to treat the acidity (Goola). }\end{array}$ \\
\hline $\begin{array}{l}\text { Orychophragmus } \\
\text { violaceus (L.) O. E. } \\
\text { Schulz. }\end{array}$ & Violaceae & Gurnash & Herb & SHM-KH-249 & $\begin{array}{l}\text { Leaves, } \\
\text { stem }\end{array}$ & $\begin{array}{l}\text { Infusion obtained from the grinded leaves of the plant is taken to } \\
\text { treat constipation and diarrhoea. }\end{array}$ \\
\hline
\end{tabular}




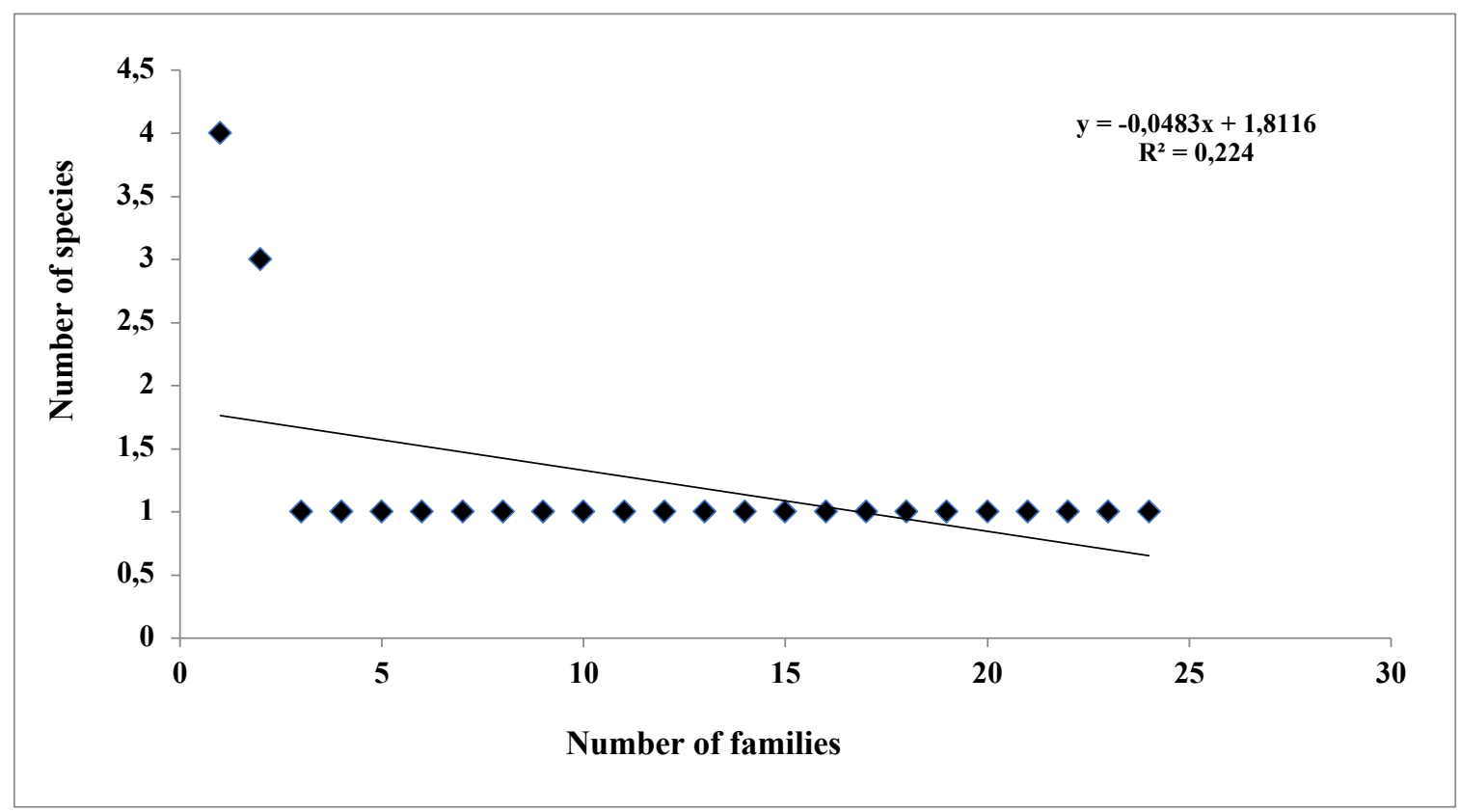

Fig. 2. Species-family relationship of flora.

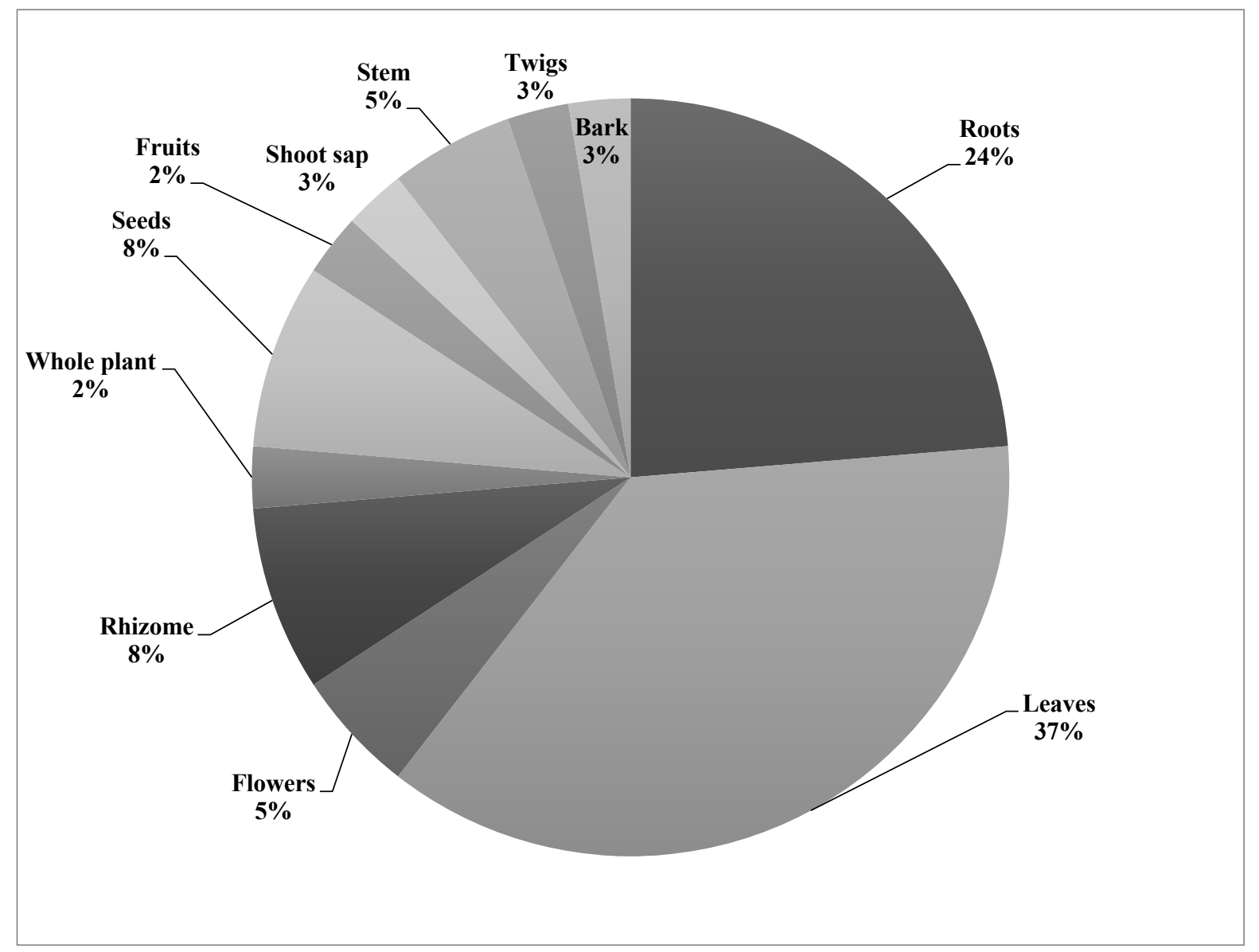

Fig. 3. Percentage of plant parts usage by the local communities in the study area 


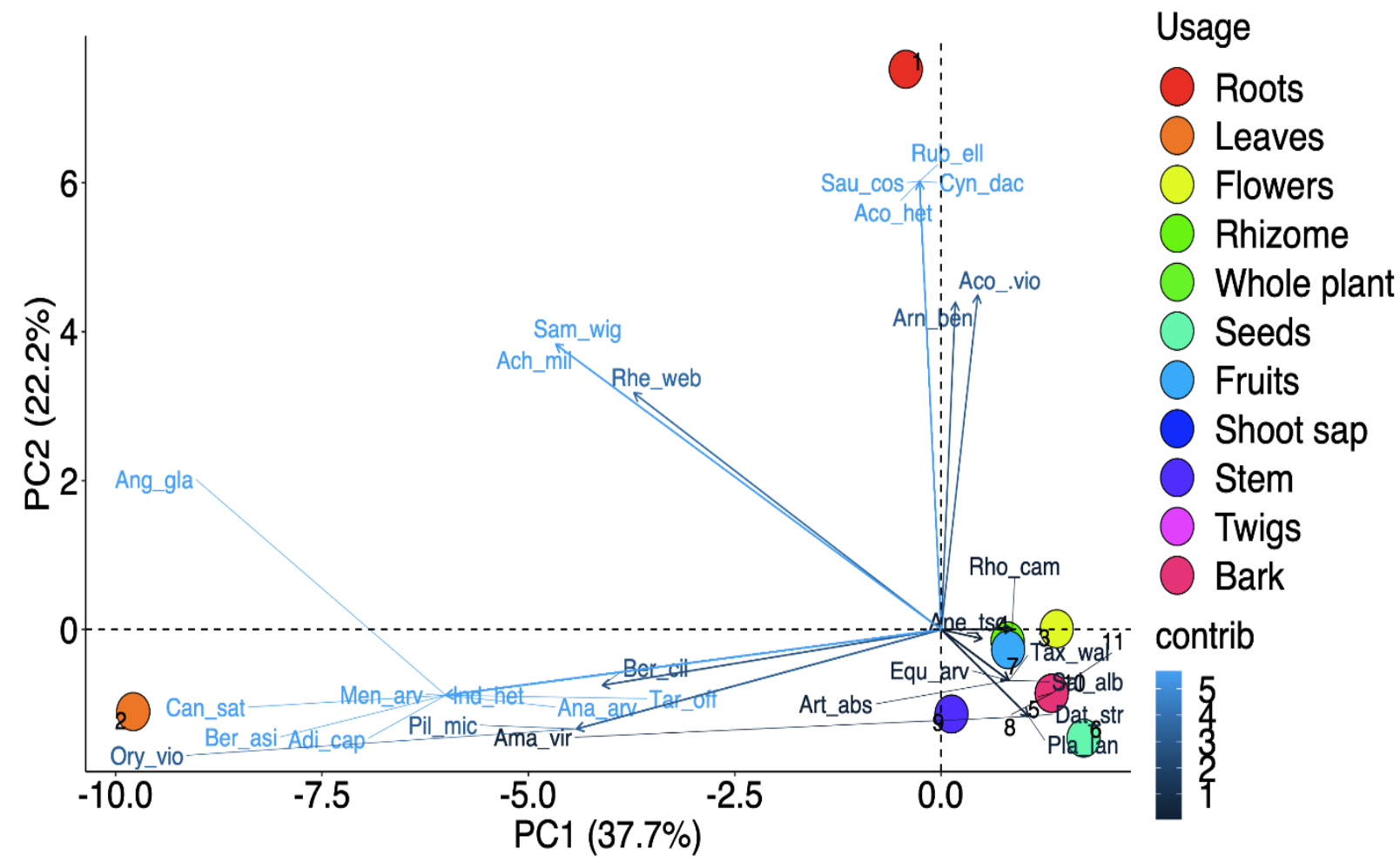

Fig. 4. Principal Component Analyses (PCA) biplot of different provisioning services investigated in the study area

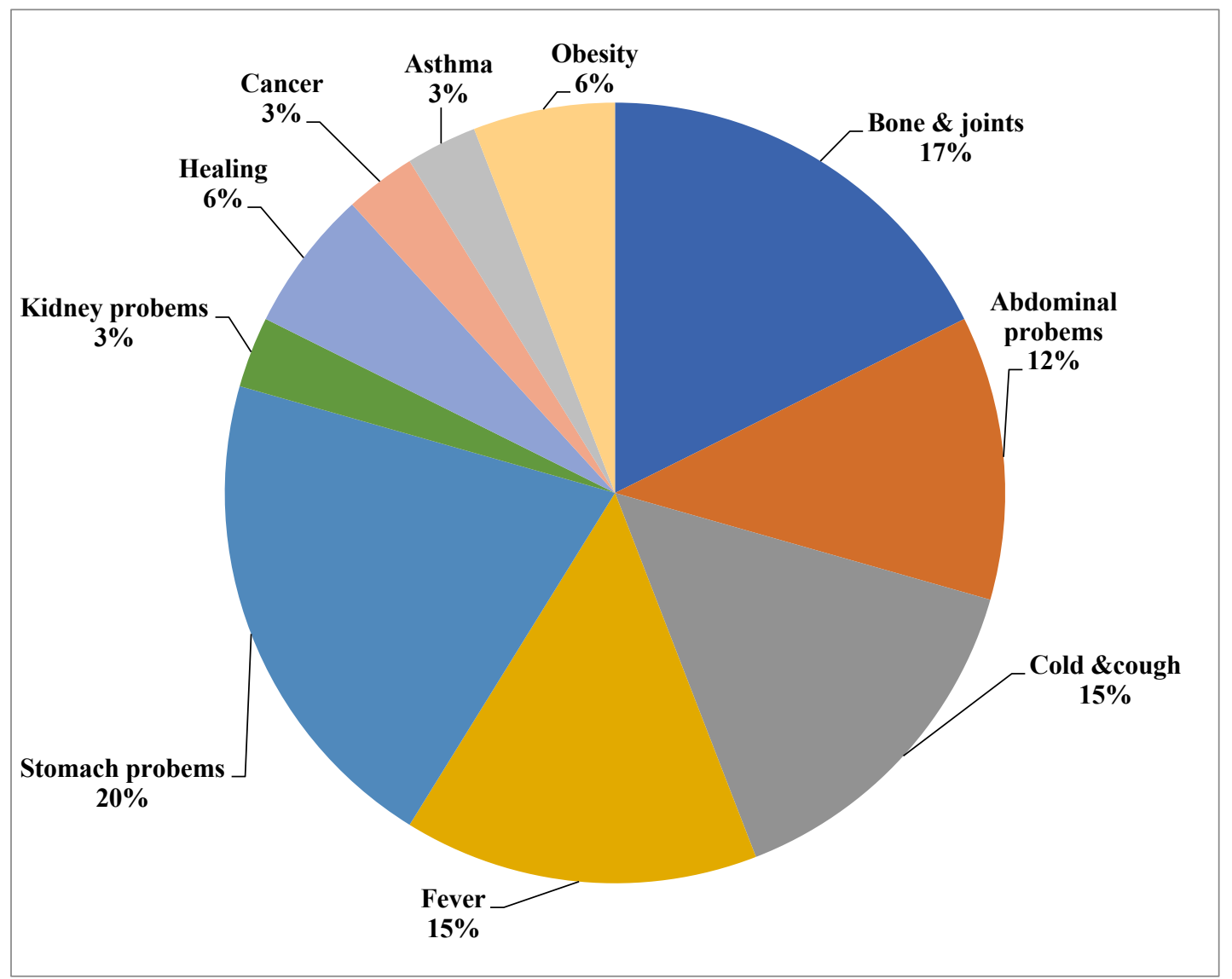

Fig. 5. Percentage of disease cured by traditional use of medicine 


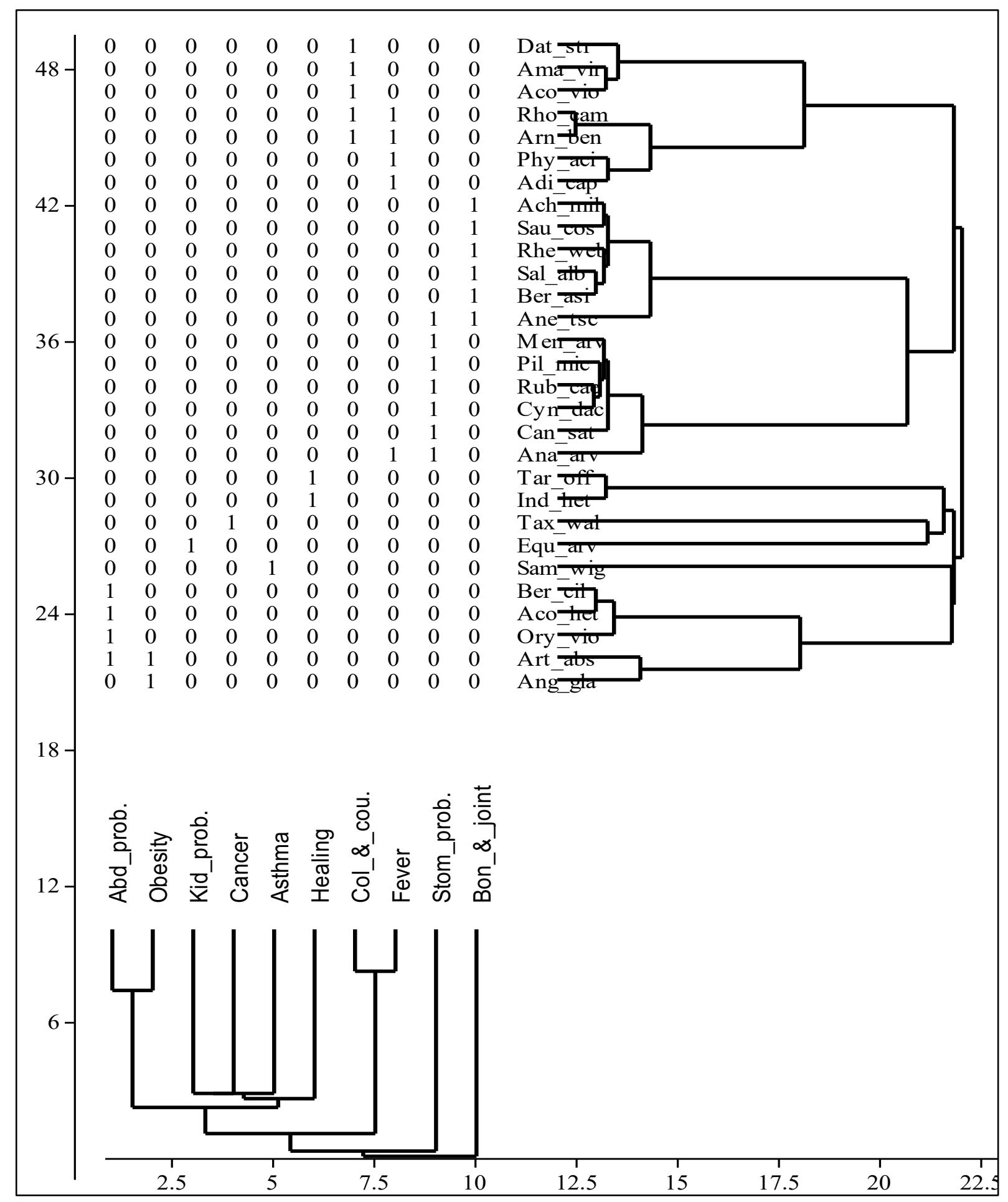

Fig. 6. Two Way Cluster Analysis based on Sorenson's similarity index of plant species and diseases cure

\section{Discussion}

The tribal people of Karnah depend upon forests for their food, shelter, medicine, fodder, fuel and other necessities of life. Identification and documentation of wild edible plants from ethnobotanical studies is important for enhancing the understanding of indigenous knowledge systems (Kunwar et al. 2008). Our present study has documented 29 plant species from 25 families in the selected study area.
Documented richness of species was similar to various other studies from different areas of the Himalaya, e.g. 38 species were reported by Ajaib et al. (2010) from district Kotli, Pakistan, Mahmood et al. (2011) described a total of 29 plant species from district Mirpur, Pakistan. Sharma et al. (2012) reported 40 plant species from Sub-Himalayan region of Uttarakhand. Hamid and Raina, (2014) reported a total of 30 plant species from Kanji Wildlife Sanctuary, North-West Himalaya. Muhammad et al. 
(2016) reported 20 plant species from Sadda Lower Kurram Agency, Pakistan (Ajaib et al. 2012; Shaheen et al. 2014).

The floristic distribution patterns of this study revealed that the results were comparable with the investigations carried out in other parts of Himalayan region where families such as Asteraceae and Ranunculaceae were the most dominant representative families. Various research studies have described Asteraceae as the dominant family from several ethnobotanical surveys (Ajaib et al. 2014; Hamid et al. 2014; Muhammad et al. 2016; Haq et al., 2020b). Owing to widespread ecological amplitude, the members of family Asteraceae acclimatize easily and adapt to arid dry habitats rapidly (Badshah et al. 2013). Further, Kayani et al. (2015) described Ranunculaceae as the most dominant family from the Alpines of Pakistan. This floristic study reported the skewed distribution of species across families and 22 families were found to be represented by only one species. These results are similar to the earlier observed findings from other parts of Himalaya (Rahman et al. 2018; Haq et al. 2019, 2020a).

Medicinal plants are often less expensive, and are perceived to have lesser side effects and toxicity and are easily available (Gurib-Fakim, 2006; Angmo et al. 2012; Aziz et al. 2018). Many ethnobotanical studies have been conducted on the traditional uses of medicinal plants in Himalayan region (Shinwari and Gilani 2003; Singh et al. 2009; Ishtiaq et al. 2012). According to our results the most frequently usage was against stomach problems followed by bone and joints cough \& cold and fever. Similar results were reported by Muhammad et al. (2016) were the most commonly treated ailments with medicinal plants from Pakistan. Singh and Lal (2008) from Lahaul-Spiti in the western Himalaya. Frequently used parts were leaves then roots followed by flowers. Due to the presence of secondary constituents leaves and flowers are often used in traditional medicine. Roots were also known to contains good concentration of bioactive compounds (Srithi and Balslev, 2009; Begum et al. 2014), and local healers (Hakeems) used the root extractions for treating various health malefactions. Different previous studies from different regions of Himalaya are in accordance with our present study (Kala et al. 2006; Singh et al. 2009; Ahmad et al. 2014; Bano et al. 2014; Abbas et al. 2017; Haq et al., 2020b).

Many important medicinal plants such as Aconitum heterophyllum Wall. ex Royle, Bergenia ciliata (Haw.) Sternb, Rheum webbianum Royle, Aucklandia costus Falc., and Taxus wallichiana
Zucc. were also reported their medicinal usage in other parts of Himalaya (Khan et al. 2013; Kayani et al. 2015; Haq et al. 2020b). Majority of the local people uses traditional medicines to overcome health problems. Topographical inaccessibility and relative accessibility of medicinal herbs play a vital role in making the traditional medicine a first choice of treatment against modern medicine (Verma et al. 2019). Due to ease of access and close proximity to the forest area and also having good knowledge of ethnomedicinal plants the local people prefered the use of traditional medicines for medication. Similar results were reported by Haq et al. (2020b) from North-Western Himalaya, India, thus supporting our findings.

\section{Conclusions}

The aim of the present study was to document the plants with medicinal attribution used by the people in Karnah (study area). Investigations support that rich information (ethno-medicinal) is mostly held by elderly people, hence documentation is essential. A total of 29 plant species belonging to 25 genera were used as medicine. Asteraceae was the largest family with $14 \%$ species. The results of preference analysis showed a significant difference in plant part usage $\left(x^{2}=70.587, d f=9, p<0.001\right)$. The highest priority of local people was for leaves (38\%). A majority of the local people (81.33\%) used traditional medicines and $49.23 \%$ regarded traditional medicines as always effective. The study emphasizes the importance of ethnomedicinal use of wild medicinal plant. Our present investigations will help to make young generations aware about the traditional knowledge related to plant, along this present study describes a useful self-care tool for the native people of the Kashmir Himalayas and other similar Himalayan mountainous region.

\section{Declarations}

Ethics approval and consent to participate: All the participants provided prior informed consent before the interviews.

Availability of data and materials: Data are available from the first author.

Competing interests: The authors declare that they have no competing interests.

Funding: This research did not receive any specific grant from funding agencies in the public, commercial, or not-for-profit sectors.

Author contributions: $\mathrm{SMH}$ carried out the field study. SMH and UY wrote the manuscript. SMH contributed in specimen identification. MUH and HAJ thoroughly revised the manuscript. All authors read and approved the final manuscript. 


\section{Literature cited}

Abbas Z, Khan SM, Alam J, Khan SW, Abbasi AM. 2017. Medicinal plants used by inhabitants of the Shigar Valley, Baltistan region of Karakorum rangePakistan. Journal of ethnobiology and ethnomedicine 13(1):1-5.

Ahmad M, Sultana S, Fazl-i-Hadi S, Ben Hadda T, Rashid S, Zafar M, Khan MA, Khan MP, Yaseen G. 2014. An Ethnobotanical study of Medicinal Plants in high mountainous region of Chail valley (District Swat-Pakistan). Journal of ethnobiology and ethnomedicine 10(1):36.

Ajaib M, Haider SK, Zikrea A, Siddiqui MF. 2014. Ethnobotanical Studies of Herbs of Agra Valley Parachinar, Upper Kurram Agency, Pakistan. International Journal of Biology and Biotechnology 11(1):71-83.

Ajaib M, Khan Z, Khan NA, Wahab M. 2010. Ethnobotanical studies on useful shrubs of district Kotli, Azad Jammu \& Kashmir, Pakistan. Pakistan Journal of Botany 42(3):1407-1415.

Ajaib M, Zaheer-ud-Din K, Siddiqui MF. 2012. Ethnobotanical study of useful climbers/twiners of district Kotli, Azad Jammu and Kashmir. International Journal of Biology and Biotechnology (Pakistan) $9(4): 421-427$

Allkin B. 2017. Useful plants-medicines: at least 28,187 plant species are currently recorded as being of medicinal use. Royal Botanic Gardens, Kew, London (UK); 2017.

Angmo K, Adhikari BS, Rawat GS. 2012. Changing aspects of traditional healthcare system in Western Ladakh, India. Journal of ethnopharmacology 143(2):621-630.

Aziz MA, Khan AH, Adnan M, Izatullah I. 2017. Traditional uses of medicinal plants reported by the indigenous communities and local herbal practitioners of Bajaur Agency, Federally Administrated Tribal Areas, Pakistan. Journal of ethnopharmacology 198:268-281.

Aziz MA, Khan AH, Adnan M, Ullah H. 2018. Traditional uses of medicinal plants used by Indigenous communities for veterinary practices at Bajaur Agency, Pakistan. Journal of Ethnobiology and Ethnomedicine 14(1):11.

Badshah L, Hussain F, Sher Z. 2013. Floristic inventory, ecological characteristics and biological spectrum of rangeland, District Tank, Pakistan. Pakistan Journal of Botany 45(4):1159-1168.

Bano A, Ahmad M, Hadda TB, Saboor A, Sultana S, Zafar M, Khan MP, Arshad M, Ashraf MA. 2014. Quantitative ethnomedicinal study of plants used in the skardu valley at high altitude of KarakoramHimalayan range, Pakistan. Journal of Ethnobiology and Ethnomedicine 10(1):43.

Begum S, Abd El Islam NM, Adnan M, Tariq A, Yasmin A, Hameed R. 2014. Ethnomedicines of highly utilized plants in the temperate Himalayan region. African Journal of Traditional, Complementary and Alternative Medicines 11(3):132-142.

Dalirsefat SB, da Silva Meyer A, Mirhoseini SZ. 2009. Comparison of similarity coefficients used for cluster analysis with amplified fragment length polymorphism markers in the silkworm, Bombyx mori. Journal of Insect Science 9(1):1-8.

Greig-Smith, P. 2010. Quantitative Plant Ecology, 3rd ed, Blackwell Scientific; Oxford, 2010.

Gurib-Fakim A. 2006. Medicinal plants: traditions of yesterday and drugs of tomorrow. Molecular aspects of Medicine 27(1):1-93.

Hamid A, Raina AK. 2014. Ethnobotanical uses of plants in and around Kanji Wildlife Sanctuary, north west Himalaya. International Journal of Science and Research 3:538-45.

Hammer Ø, Harper DA, Ryan PD. 2001. PAST: Paleontological statistics software package for education and data analysis. Palaeontologia Electronica 4(1):9.

Haq SM, Malik ZA, Rahman IU. 2019. Quantification and characterization of vegetation and functional trait diversity of the riparian zones in protected forest of Kashmir Himalaya, India. Nordic Journal of Botany 37(11):1-11.

Haq SM, Calixto ES, Singh B. 2020a. Investigation of the traditional knowledge of economically important plants in proper Neelum Valley, District Bandipora, Jammu \& Kashmir, North-Western Himalaya, India. In Singh, B. and Sharma, Y.P. (Eds), Plants of Novel drug molecules Ethnobotany to ethnopharmacology, pp 287-302. ISBN: 9789389571943.

Haq SM, Singh B. 2020b. Ethnobotany as a science of preserving traditional knowledge: A case study of investigating uses of wild plants of District Reasi, J\&K State (North-western Himalaya), India. Springer Nature Singapore Pte Ltd. 2020. B. Singh (ed.), Botanical Leads for Drug Discovery, https://doi.org/10.1007/978-981-15-5917-4_13.

Ishtiaq M, Mumtaz AS, Hussain T, Ghani A. 2012. Medicinal plant diversity in the flora of Leepa Valley, Muzaffarabad (AJK), Pakistan. African Journal of Biotechnology 11(13):3087-98. 
Jadhav VD, Mahadkar SD, Valvi SR. 2011. Documentation and ethnobotanical survey of wild edible plants from Kolhapur district. Recent research in Science and Technology 3(12):58-63.

Kala CP, Dhyani PP, Sajwan BS. 2006. Developing the medicinal plants sector in northern India: challenges and opportunities. Journal of Ethnobiology and Ethnomedicine 2(1):32.

Kayani S, Ahmad M, Sultana S, Shinwari ZK, Zafar M, Yaseen G, Hussain M, Bibi T. 2015. Ethnobotany of medicinal plants among the communities of Alpine and Sub-alpine regions of Pakistan. Journal of Ethnopharmacology 164:186-202.

Khan A, Gilani SS, Hussain F, Durrani MJ. 2003. Ethnobotany of Gokand valley, district Buner, Pakistan. Pakistan Journal of Biological Sciences 6(362):9.

Khan SM, Page S, Ahmad H, Shaheen H, Ullah Z, Ahmad M, Harper DM. 2013. Medicinal flora and ethnoecological knowledge in the Naran Valley, Western Himalaya, Pakistan. Journal of Ethnobiology and Ethnomedicine 9(1):4.

Kumar M, Sheikh MA, Bussmann RW. 2011. Ethnomedicinal and ecological status of plants in Garhwal Himalaya, India. Journal of Ethnobiology and Ethnomedicine. 7(1):32.

Kunwar RM, Bussmann RW. 2008. Ethnobotany in the Nepal Himalaya. Journal of Ethnobiology and Ethnomedicine 4(1):24.

Mahmood A, Mahmood A, Shaheen H, Qureshi RA, Sangi Y, Gilani SA. 2011. Ethno medicinal survey of plants from district Bhimber Azad Jammu and Kashmir, Pakistan. Journal of Medicinal Plants Research 5(11):2348-60.

Mahmood A, Qureshi RA, Mahmood A, Sangi Y, Shaheen H, Ahmad I, Nawaz Z. 2011. Ethnobotanical survey of common medicinal plants used by people of district Mirpur, AJK, Pakistan. Journal of Medicinal Plants Research 5(18):44934498.

Med JA. 2017. The Wiled RET edible plants consumed by the Irula tribals of Walayar valley, Southern Western Ghats of India. Journal of Ayurvedic and Herbal Medicine 3(4):205-9.

Muhammad S, Hussain M, Rahman IU, Shah GM, ljaz F, Ullah K. 2016. Indigenous medicinal usage of family Asteraceae in Sadda Lower Kurram Agency: A case study. Asian Journal of Science \& Technology 7(12):3998-4003.

Pieroni A, Nebel S, Quave C, Münz H, Heinrich M. 2002. Ethnopharmacology of liakra: traditional weedy vegetables of the Arbëreshë of the Vulture area in southern Italy. Journal of ethnopharmacology 81(2):165-185.

Rahman IU, Afzal AF, Iqbal ZA, ljaz F, Ali N, Asif M, Alam J, Majid A, Hart R, Bussmann RW. 2018. First insights into the floristic diversity, biological spectra and phenology of Manoor Valley, Pakistan. Pakistan Journal of Botany 50(3):1113-1124.

Rahman IU, Ijaz F, Afzal A, Iqbal Z, Ali N, Khan SM. 2016. Contributions to the phytotherapies of digestive disorders: Traditional knowledge and cultural drivers of Manoor Valley, Northern Pakistan. Journal of Ethnopharmacology 192:30-52.

Rashid A, Anand VK, Serwar J. 2008. Less known wild edible plants used by the Gujjar tribe of district Rajouri, Jammu and Kashmir State. International Journal of Botany 4(2):219-224.

Roy V. 2020. Integrating Indigenous Systems of Medicines in the Healthcare System in India: Need and Way Forward. In: Sen S, Chakraborty R (eds) Herbal Medicine in India. Springer, Singapore. https://doi.org/10.1007/978-981-13-7248-3_

Setalaphruk C, Price LL. 2007. Children's traditional ecological knowledge of wild food resources: a case study in a rural village in Northeast Thailand. Journal of Ethnobiology and Ethnomedicine 3(1):33.

Sewell RD, Rafieian-Kopaei M. 2014. The history and ups and downs of herbal medicines usage. Journal of HerbMed Pharmacology 3(1):1-3.

Shaheen H, Islam ME, Ullah Z. 2014. Indigenous ethnobotanical remedies practiced to cure feminine diseases in tribal communities of Kashmir Himalayas. International Journal of Phytomedicine 6(1):103.

Sharma J, Gairola S, Gaur RD, Painuli RM. 2012. The treatment of jaundice with medicinal plants in indigenous communities of the Sub-Himalayan region of Uttarakhand, India. Journal of Ethnopharmacology 143(1):262-291.

Shinwari ZK, Gilani SS. 2003. Sustainable harvest of medicinal plants at Bulashbar Nullah, Astore (northern Pakistan). Journal of Ethnopharmacology 84(2-3):289-98.

Singh A, Lal M, Samant SS. 2009. Diversity, indigenous uses and conservation prioritization of medicinal plants in Lahaul valley, proposed Cold Desert Biosphere Reserve, India. International Journal of Biodiversity Science \& Management 5(3):132-154.

Singh GS. 2004. Indigenous knowledge and conservation practices in tribal society of Western Himalaya: A case study of Sangla Valley. Studies of Tribes and Tribals 2(1):29-35. 
Singh KN, Lal B. 2008. Ethnomedicines used against four common ailments by the tribal communities of Lahaul-Spiti in western Himalaya. Journal of Ethnopharmacology 115(1):147-59.

Sorensen TA. 1948. A method of establishing groups of equal amplitude in plant sociology based on similarity of species content and its application to analyses of the vegetation on Danish commons. Biologiske Skar. 5:1-34.

Srithi K, Balslev H, Wangpakapattanawong $\mathrm{P}$, Srisanga P, Trisonthi C. 2009. Medicinal plant knowledge and its erosion among the Mien (Yao) in northern Thailand. Journal of Ethnopharmacology 123(2):335-42.

Stewart RR. 1972. An annotated catalogue of the vascular plants of West Pakistan and Kashmir. Fakhri Printing Press, Karachi.

Turner WR, Tjørve E. 2005. Scale-dependence in species-area relationships. Ecography 28(6):721-30.

Verma VR, Gandhi S, Dash U. 2019. Traversing the margins: Access to healthcare by Bakarwals in remote and conflict-prone Himalayan regions of Jammu and Kashmir. Pastoralism 9(1):2.

Verpoorte R, Choi YH, Kim HK. 2005. Ethnopharmacology and systems biology: a perfect holistic match. Journal of Ethnopharmacology 100(12):53-6.

World Health Organization. Traditional Medicine, 2003, Fact sheet No 134. http://www.who.int/mediacentre/factsheets/fs134/en /

Yuan H, Ma Q, Ye L, Piao G. 2016. The traditional medicine and modern medicine from natural products. Molecules 21(5):559. 